\title{
COMPLEX FORMATION AND LIQUID-LIQUID EXTRACTION OF THE COBALT(II) BY 2-HYDROXYTHIOPHENOL AND ITS DERIVATIVES IN THE PRESENCE OF HYDROPHOBIC AMINES SYSTEM
}

\author{
A.Z.Zalov $^{1}$, N.A.Verdizade ${ }^{1}$, G.V.Babayeva ${ }^{1}$, Sh.A.Ibrahimova ${ }^{2}$ \\ ${ }^{1}$ Azerbaijan State Pedagogical University \\ ${ }^{2}$ Baku State University \\ Zalov1966@mail.ru
}

Received 25.10.2017

\begin{abstract}
Mixed-ligand complexes of cobalt(II) with hydroxythiophenols (OP) \{2-hydroxythiophenol (HTP) and its derivatives (2-hydroxy-5-aminthiophenol (HATP), 4-hydroxy-3-thiolsulfonic acid (HTSA), 4hydroxy-3-thiolbenzoic acid (HTBA), 4-Nitro-2-hydroxythiophenol (HNTP) $\}$ in the presence of hydrophobic amines (Am) have been studied by spectrophotometric methods. Extraction of mixed ligand complexes is maximal at $\mathrm{pH}$ 3.6-6.3. The optimum conditions for the formation and extraction of mixed-ligand compounds have been found and the ratios of components the complexes have been determined. The Beer's law was applicable in the range of $0.05-3.2 \mu \mathrm{g} / \mathrm{ml}$. The effect of foreign ions and reagents on the extraction was studied. The new method is free from common interferences. A procedure has been developed for extraction - spectrophotometric determination of cobalt in different objects.
\end{abstract}

Keywords: cobalt, solvent, spectrophotometry, ion-associate, hydrophobic amines, hydroxythiophenol.

\section{doi.org/10.32737/0005-2531-2019-4-39-47}

\section{Introduction}

Cobalt is a transition element of high industrial importance because of its valuable alloying, dyeing, magnetic, catalytic and plating properties. It is also of biological significance due to its ability to be an active center of coenzymes, e.g. vitamin B12 [1]. A great variety of photometric reagents is known for the determination of cobalt. However, the studies aiming to find and investigate new photometric reagents with different functional groups are still going on. For photometric determination of cobalt there are quite selective reagents $o$-nitrozofenole group or a similar structure with the oxime group [2].

Oxyphenolate, oxythiophenolate and dithiophenolate complexes of cobalt are insoluble in chloroform, while mixed-ligand complexes with hydrophobic amines and aminophenols easily dissolve in various organic solvents [3-9]. In this respect, a very promising reagent is oxythiophenol (OP), which contains one hydroxyl and one sulphohydryl groups and is a sulfur-containing analogue of mononuclear polyphenols with one oxygen atoms replaced with sulfur atoms. The present work is devoted to studying the reaction of a complex formation of $\mathrm{Co}$ (II) with oxythiophenol (OP) in the presence of hydrophobic amines (Am). Oxythiophenols 2-hydroxythiophenol (HTP) and its derivatives (2-hydr- oxy-5-aminthiophenol (HATP), 4-hydroxy-3thiolsulfonic acid (HTSA), 4-hydroxy-3-thiolbenzoic acid (HTBA), 4-Nitro-2-hydroxythiophenol (HNTP) were used in the presence of hydrophobic amines (Am). As hydrophobic amine 2(N, N-dimethylaminomethyl)-phenol $\left(\mathrm{AP}_{1}\right)$ and 2(N,N-dimethylaminomethyl)-4-methylphenol $\left(\mathrm{AP}_{2}\right)$ were used.

\section{Experimental part}

Reagents and apparatus. A stock solution $(1 \mu \mathrm{g} / \mathrm{ml})$ of cobalt(II) was prepared by dissolving in water an exact linkage $\mathrm{CoSO}_{4} \cdot 7 \mathrm{H}_{2} \mathrm{O}$ in water containing $2 \mathrm{ml}$ concentrated $\mathrm{H}_{2} \mathrm{SO}_{4}$, and diluted by water to 1 liter [10]. The concentration of the cobalt solution was adjusted gravimetrically [11]. Solutions of OP and Am in chloroform $(0.01 \mathrm{M})$ were used. OP were synthesized according to the procedure [12]. Their purity was verified by melting point determination and paper chromatography. The synthesized compound was identified by NMR and IR spectroscopy (Table 1). To create the optimal acidity, $0.1 \mathrm{M}$ solutions of $\mathrm{KOH}$ and $\mathrm{HCl}$ or ammonium acetate buffers were applied. The extractant was purified chloroform.

The absorbance of the extracts was measured using a SF 26 spectrophotometer and KFK2 photocolorimeter. Glass cells with optical path 
Table 1. The research results of IR and NMR spectroscopy

\begin{tabular}{|c|c|c|}
\hline Reagent & IR (KBr) & ${ }^{1} \mathrm{H}$ NMR $\left(300,18\right.$ МГц, $\left.\mathrm{C}_{6} \mathrm{D}_{6}\right)$ \\
\hline HTP & $\begin{array}{l}3470 \mathrm{~cm}^{-1} v(\mathrm{OH}), 3050 \mathrm{~cm}^{-1} v(\mathrm{CH}), 2580 \mathrm{~cm}^{-1} \\
v(\mathrm{SH}), 1580 \mathrm{~cm}^{-1}\left(\mathrm{C}_{6} \mathrm{H}_{5}\right) .\end{array}$ & $\begin{array}{l}\delta 5.48(\mathrm{~s}, 1 \mathrm{H}-\mathrm{OH}), \delta 3.57(\mathrm{~s}, 1 \mathrm{H},-\mathrm{SH}), \delta 7.8(\mathrm{~s}, 2 \mathrm{H} \\
\mathrm{Ar}-\mathrm{H}), \delta 6.95(\mathrm{~s}, 1 \mathrm{H}, \text { Ar-H }), \delta 7.05(\mathrm{~s}, 1 \mathrm{H}, \mathrm{Ar}-\mathrm{H}) .\end{array}$ \\
\hline HATP & $\begin{array}{l}3460 \mathrm{~cm}^{-1} v(\mathrm{OH}), 3050 \mathrm{~cm}^{-1} v(\mathrm{CH}), 2570 \mathrm{~cm}^{-1} \\
v(\mathrm{SH}), 1418 \text { and } 1130 \mathrm{~cm}^{-1} v\left(-\mathrm{NH}_{2}\right), 1555 \mathrm{~cm}^{-1} \\
v\left(\mathrm{C}_{6} \mathrm{H}_{5}\right) \text {. }\end{array}$ & $\begin{array}{l}\delta 5.24(\mathrm{~s}, 1 \mathrm{H}-\mathrm{OH}), \delta 3.32(\mathrm{~s}, 1 \mathrm{H},-\mathrm{SH}), \delta 7.11(\mathrm{~s}, 2 \mathrm{H}, \\
\text { Ar-H), } \delta 2.38\left(\mathrm{~s}, 2 \mathrm{H},-\mathrm{NH}_{2}\right), \delta 7.05(\mathrm{~s}, 1 \mathrm{H}, \quad \text { Ar-H). }\end{array}$ \\
\hline HTSA & $\begin{array}{l}3465 \mathrm{~cm}^{-1} v(\mathrm{OH}), 3050 \mathrm{~cm}^{-1} v(\mathrm{CH}), 2572 \mathrm{~cm}^{-1} \\
v(\mathrm{SH}), 1210 \text { and } 1130 \mathrm{~cm}^{-1} v\left(\mathrm{SO}_{3} \mathrm{H}\right), 1565 \mathrm{~cm}^{-1} \\
v\left(\mathrm{C}_{6} \mathrm{H}_{5}\right) \text {. }\end{array}$ & $\begin{array}{l}\delta 5.39(\mathrm{~s}, 1 \mathrm{H},-\mathrm{OH}), \delta 3.42(\mathrm{~s}, 1 \mathrm{H}, 1 \mathrm{SH}), \delta 7.21(\mathrm{~s}, 2 \mathrm{H}, \\
\mathrm{Ar}-\mathrm{H}), \delta 2.59\left(\mathrm{~s}, \mathrm{H},-\mathrm{SO}_{3} \mathrm{H}\right), \delta 7.15(\mathrm{~s}, 1 \mathrm{H}, \mathrm{Ar}-\mathrm{H}) .\end{array}$ \\
\hline HTBA & $\begin{array}{l}3458 \mathrm{~cm}^{-1} v(\mathrm{OH}), 2568 \mathrm{~cm}^{-1} v(\mathrm{SH}), 3040 \mathrm{~cm}^{-1} \\
v(\mathrm{CH}), 1420 \text { and } 1300 \mathrm{~cm}^{-1} v(\mathrm{COOH}), 1535 \mathrm{~cm}^{-1} \\
v\left(\mathrm{C}_{6} \mathrm{H}_{5}\right) .\end{array}$ & $\begin{array}{l}\delta 5.15(\mathrm{~s}, 1 \mathrm{H},-\mathrm{OH}), \delta 3.28(\mathrm{~s}, 1 \mathrm{H},-\mathrm{SH}), \delta 7.05(\mathrm{~s}, 2 \mathrm{H}, \\
\mathrm{Ar}-\mathrm{H}), \delta 1.42(\mathrm{~s}, 1 \mathrm{H}, \mathrm{COOH}), \delta 7.26(\mathrm{~s}, 1 \mathrm{H},-\mathrm{Ar}-\mathrm{H}) .\end{array}$ \\
\hline HNTP & $\begin{array}{l}3462 \mathrm{~cm}^{-1} v(\mathrm{OH}), 2564 \mathrm{~cm}^{-1} v(\mathrm{SH}), 3045 \mathrm{~cm}^{-1} \\
v(\mathrm{CH}), 1700 \mathrm{~cm}^{-1} v\left(\mathrm{NO}_{2}\right), 1535 \mathrm{~cm}^{-1} v\left(\mathrm{C}_{6} \mathrm{H}_{5}\right)\end{array}$ & $\begin{array}{l}\delta 5.16(\mathrm{~s}, 1 \mathrm{H},-\mathrm{OH}), \delta 3.25(\mathrm{~s}, 1 \mathrm{H},-\mathrm{SH}), \delta 7.18(\mathrm{~s}, 2 \mathrm{H}, \\
\mathrm{Ar}-\mathrm{H}), \delta 7.41(\mathrm{~s}, 1 \mathrm{H},-\mathrm{Ar}-\mathrm{H}) .\end{array}$ \\
\hline
\end{tabular}

of 5 or $10 \mathrm{~mm}$ were used. $\mathrm{pH}$ of aqueous phase was measured using an I-120.2 potentiometer with a glass electrode. Muffle furnace was used for dissolution of the samples.

\section{General procedure}

General procedure for the Determination of Cobalt(II). Portions of stock solutions of cobalt(II) varying from 0.1 to $1.0 \mathrm{ml}$ with a $0.1-\mathrm{ml}$ step, a $2.2 \mathrm{ml}$ portion of a $0.01 \mathrm{M}$ solution of OP, and a $2.5 \mathrm{ml}$ portion of a $0.01 \mathrm{M}$ solution of Am were placed into calibrated test tubes with ground-glass stoppers (the volume of the organic phase was $5 \mathrm{ml}$ ). The required value of $\mathrm{pH}$ was adjusted by adding $1 \mathrm{M} \mathrm{HCl}$. The volume of the aqueous phase was increased to $20 \mathrm{ml}$ by using distilled water. In 15 minnute after the complete separation of the phases, the organic phase was separated from the aqueous phase and the absorbance of the extracts was measured on KFK-2 at room temperature and $540 \mathrm{~nm}(\ell=0.5 \mathrm{~cm})$.

Determination of cobalt(II) in steel [Steel M 441(0.012\% Co) and НMц2.5/M 627x $(0.055 \% \mathrm{Co})]$. A weighed sample of $0.2 \mathrm{~g}$ was dissolved in $20 \mathrm{ml}$ of $\mathrm{H}_{2} \mathrm{SO}_{4}(1: 1)$ was oxidized with a few drops of concentrated nitric acid and evaporated twice lo vapor $\mathrm{SO}_{3}$. The precipitated salt was dissolved in $20 \mathrm{ml}$ of $15 \%$ tartaric acid under heating, the solution was cooled, adjusted with water to $100 \mathrm{ml}$ in a volumetric flask, stirred and filtered. An aliquot of $5 \mathrm{ml}$ was put into a separatory funnel then, was added $1 \mathrm{ml}$ of $10 \%$ hydroxylamine solution, 1 $\mathrm{ml}$ of $3 \%$ ascorbic acid were added andthere was determined cobalt used in the proposed procedures.

Determination of $\mathrm{Co}(\mathrm{II})$ in sewage water and bottom sediments. 11 taken for analysis of waste water is evaporated to obtain a precipitate, it is not boiled. The precipitate was dissolved in $5 \mathrm{ml}$ of $\mathrm{HNO}_{3}$, was transferred to a 50 $\mathrm{ml}$ flask and diluted to the mark with water.

Determination of Co(II) in plant. A portion of beans ( $10 \mathrm{~g})$ was crushed and dried in a porcelain dish at $120^{\circ} \mathrm{C}$. The dry residue is heated in a muffle furnace at $500^{\circ} \mathrm{C}$. The ash was dissolved in diluted $(1: 1) \mathrm{HNO}_{3}$ and evaporate to moist salts, which are then dissolved in water, filtered into a volumetric flask of $100 \mathrm{ml}$. The cobalt content is determined with OP and AP.

\section{Results and discussion}

Charge of the complexes. The charge of the $\mathrm{Co}$ (II)-OP binary complexes was determined by electromigration and ion-exchange. Experiments on electromigration in a U-shaped tube and on sorption on EDE-10P anion exchanger demonstrated the anionic nature of the complexes. Under the experimental conditions, these red binary complexes were insoluble in nonpolar organic solvents. However, when AP were introduced the formation of electroneutral chloroform extractable ternary complexes was observed.

Choice of organic solvent. For the extraction of complexes we used $\mathrm{CHCl}_{3}, \mathrm{CCl}_{4}$, $\mathrm{C}_{6} \mathrm{H}_{6}, \mathrm{C}_{6} \mathrm{H}_{5} \mathrm{CH}_{3}, \mathrm{C}_{6} \mathrm{H}_{4}\left(\mathrm{CH}_{3}\right)_{2}, \mathrm{C}_{6} \mathrm{H}_{5} \mathrm{Cl}, \mathrm{C}_{2} \mathrm{H}_{4} \mathrm{Cl}_{2}$, 
isobutanol and isopentanol. The extractivity of the complexes was estimated by the distribution coefficient and recovery. $\mathrm{CHCl}_{3}, \mathrm{C}_{6} \mathrm{H}_{5} \mathrm{Cl}$, $\mathrm{C}_{2} \mathrm{H}_{4} \mathrm{Cl}_{2}$ appeared to be the best extractants. All the further investigations were carried out with chloroform. The concentration of cobalt in the organic phase was determined with 2-nitroso-1naphtol [11] by photometric measurements after back extraction, while in the aqueous phase it was determined by the difference. The basicity of Am hardly influences the recovery of niobium. After a single extraction with chloroform, 96.9-99.2\% of cobalt was extracted as an ion associate.

Effect of $\mathrm{pH}$ of the aqueous phase. The effect of $\mathrm{pH}$ on the formation of $\mathrm{Co}$ (II)-OP-AP complex was studied, in order to find a suitable $\mathrm{pH}$ that can be adopted in the determination of cobalt(II) (Figure 1). The absorbance was found to be maximum in the $\mathrm{pH}$ range $2.3-7.3$. Hence further analytical investigations were carried out in media of $\mathrm{pH}$ 3.6-6.3 (Table 1). Extraction of $\mathrm{Co}$ (II) enhanced with the increase in the acidity of the initial solution; the further increase in acidity led to the gradual decrease of recovery, which was obviously associated with a decrease in the concentration of the ionized form of OP. Probably, it is present in the solution in the non-dissociated state. At $\mathrm{pH} \geq 7.2$, the complexes were hardly extracted, obviously because of the decrease in the degree of Am protonation.

Influence of reagent concentration and incubation time. For the formation and extraction of mixed-ligand complex (MLC), a 20-25fold excess of complexing reagents is required; for example, the optimal conditions for formation and extraction of these compounds are provided by $(1.10-2.25) \times 10^{-3} \mathrm{M}$ OP and $(0.92-$ $1.24) \cdot 10^{-3} \mathrm{M}$ AP. A large excess of hydrophobic amine interferers with the determination. However it was found that the presence of excess of the reagent solution does not alter the absorbance of the color reaction. Unlike singleligand complexes, mixed-ligand complexes of $\mathrm{Co}$ (II) with OP and AP were stable in aqueous and organic solvents and did not decompose for two days, or over a month after extraction. The required duration of the phase contact was 10 $\min$ (Figure 2).

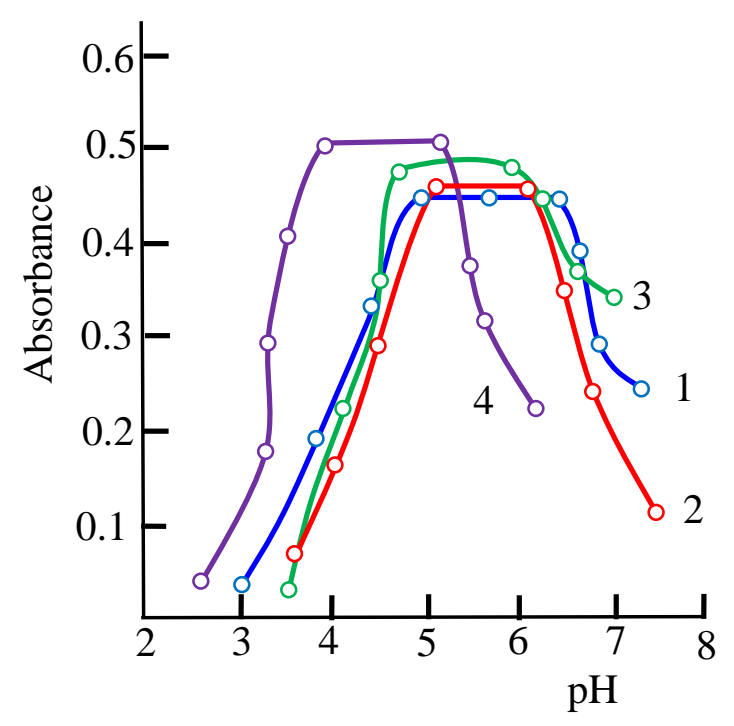

Fig. 1. Absorbance of Co-HITP-OP extracts function of the $\mathrm{pH}$ of the aqueous phase: 1 - Co-HATP-AP, 2 - Co-HTP-AP, 3 Co-HTST-AP $2,4-$ Co-HNTP-AP $2 ; C_{\mathrm{Co}(\mathrm{II})}=$ $1.7 \cdot 10^{-5} \mathrm{~mol} / \mathrm{l}, \quad C_{\mathrm{OP}}=2.0 \cdot 10^{-3} \mathrm{~mol} / \mathrm{l}^{-1}, \quad \mathrm{C}_{\mathrm{AP}}=$ $2.5 \cdot 10^{-3} \mathrm{~mol} / \mathrm{l}^{-1} ; \lambda=540 \mathrm{~nm}, \mathrm{KFK}-2, l=0.5 \mathrm{~cm}$.

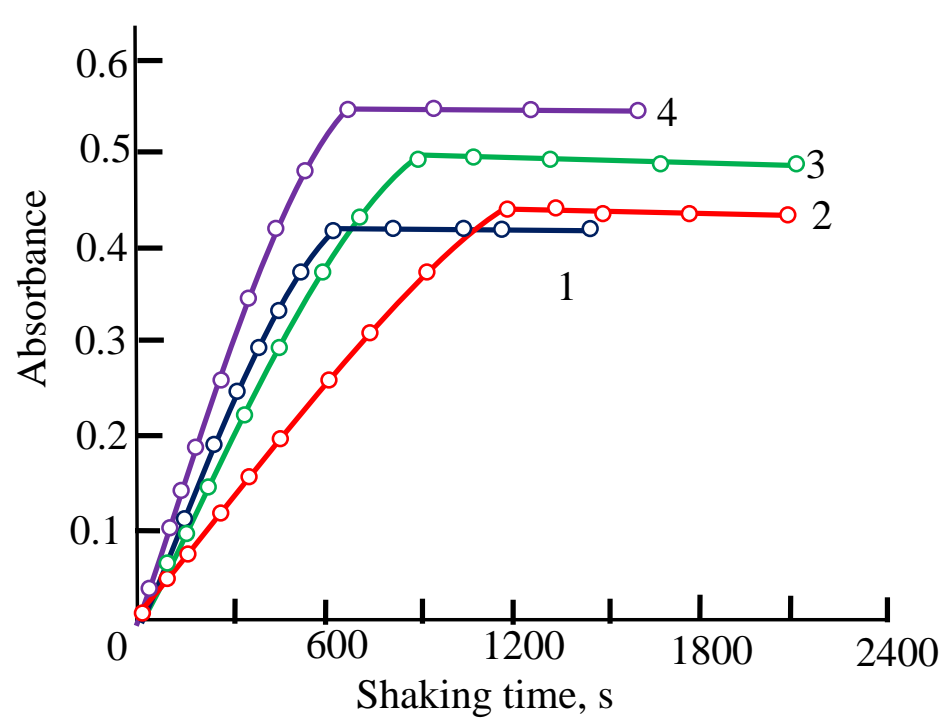

Fig. 2. Effect of shaking time on the absorbance: 1 - Co-HATP-AP $2,2-\mathrm{Co}-\mathrm{HTP}-\mathrm{AP}_{2}, 3-\mathrm{Co}-$ HTST-AP, $4-$ Co-HNTP-AP ${ }_{2} ; C_{\mathrm{Co}(\mathrm{II})}=1.7 \cdot 10^{-5}$ $\mathrm{mol} / \mathrm{l}, \mathrm{pH} 4.0-6.0, \lambda=540 \mathrm{~nm}, \mathrm{KFK}-2, l=0.5 \mathrm{~cm}$. 
Electronic absorption spectra. Neither the metal ion nor the reagent has appreciable absorbance at specified wave lengths. Hence further studies were carried out at $540-565 \mathrm{~nm}$ (Figure 3). The reagent has minimum absorbance at the maximum absorbance of the complex. Hence further absorbance measurements were made at $540 \mathrm{~nm}$.

Stoichiometry of the complexes and the mechanism of complexation. Starik-Barbanel relative yield method, equilibrium shift method, crossed lines method and Asmus' method were employed to elucidate the composition of the complex [13]. The results suggest the complex composition of 1:2:2 (Co:OP:AP). The formation of MLC can be presented in the following way. When cobaltion interact with two molecules of OP, they form doubly-charged anionic complexes, which are extracted with two molecules of protonated AP. Formed ion-association complex between anionic chelates of cobalt(II) with OP and hydrophobic aromatic amines.

Calculation of extent of polymerization of complexes was carried out on the equation [9]. The made calculations showed that MLC in an organic phase won't be polymerized and are in a monomeric form $(\gamma=1.05-1.12)$. The values of the molar absorption coefficients $\left(\varepsilon_{\mathrm{k}}=(2.62-\right.$ $3.01) \cdot 10^{4} 1 \mathrm{~mol}^{-1} \mathrm{~cm}^{-1}$ ), biphase stability constants $(\lg \beta=10.02-10.79)$, the extraction constants of the complexes $\left(\lg K_{\mathrm{ex}}=\lg \beta+\lg D=\right.$ 12.50-13.68) and the distribution coefficient $\left(\lg D=[\mathrm{Co}]_{\text {org }} /[\mathrm{Co}]_{\mathrm{aq}}=2.19-2.90\right)$, as well as the recovery of cobalt $\left(R=D / 100+\mathrm{V}_{\mathrm{aq}} / \mathrm{V}_{\text {org }}=\right.$ 97.5 - 99.5) are determined [13] (Table 1) [14].

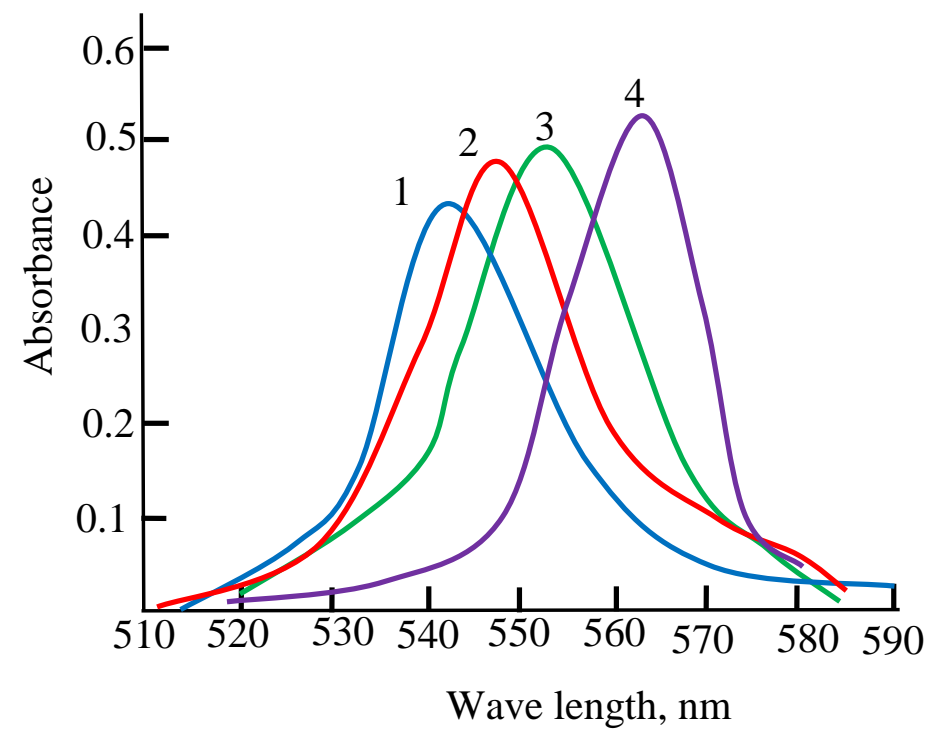

Fig. 3. Absorption of mixed-ligand complexes: 1 - Co-HATP-AP 2,2 - Co-HTP-AP, 3 - CoHTST $-\mathrm{AP}_{2}, 4-\mathrm{Co}-\mathrm{HNTP}-\mathrm{AP}_{2} ; \mathrm{C}_{\mathrm{Co}(\mathrm{II})}=$ $1.7 \cdot 10^{-5} \mathrm{~mol} / 1, \mathrm{C}_{\mathrm{OP}}=(1.10-2.25) \cdot 10^{-3} \mathrm{~mol} / 1$, $C_{\mathrm{AP}}=(0.92-1.24) \cdot 10^{-3} \mathrm{~mol} / \mathrm{l} ; \lambda=540 \mathrm{~nm}, \mathrm{pH}$ $4.0-6.0, \mathrm{KFK}-2, \ell=0.5 \mathrm{~cm}$.

Table 1. Optical characteristics, precision and accuracy of the spectrophotometric determination of Co(II) with OP and AP

\begin{tabular}{|c|c|c|c|c|c|c|c|c|c|}
\hline Compound & $\begin{array}{l}\text { The } \mathrm{pH} \text { range } \\
\text { of education } \\
\text { and extraction }\end{array}$ & $\begin{array}{l}\text { The } \mathrm{pH} \\
\text { range of } \\
\text { maximum } \\
\text { extraction }\end{array}$ & $\mathrm{R}, \%$ & $\operatorname{lgD}$ & $\begin{array}{c}\lambda_{\max } \\
\mathrm{nm}\end{array}$ & $\varepsilon \cdot 10^{-4}$ & $\lg \beta$ & $\lg K_{\mathrm{ex}}$ & $\begin{array}{c}\text { Working } \\
\text { range } / \mu \mathrm{g} \\
5 \mathrm{ml}\end{array}$ \\
\hline Co-HATP-AP 1 & $3.5-7.2$ & $4.8-6.2$ & 97.5 & 2.19 & 540 & 2.62 & 10.65 & 12.84 & $1.40-95$ \\
\hline Co-HATP-AP 2 & $3.6-7.3$ & $4.9-6.3$ & 97.7 & 2.23 & 542 & 2.68 & 10.79 & 13.02 & $1.38-95$ \\
\hline Co-HTP-AP 1 & $3.3-7.0$ & $4.5-5.9$ & 97.9 & 2.27 & 545 & 2.70 & 10.42 & 12.69 & $1.36-96$ \\
\hline Co-HTP-AP ${ }_{2}$ & $3.5-7.2$ & $4.7-6.0$ & 98.0 & 2.29 & 548 & 2.76 & 10.57 & 12.86 & $1.35-98$ \\
\hline $\mathrm{Co}-\mathrm{HTST}-\mathrm{AP}_{1}$ & $2.8-6.6$ & $4.2-5.6$ & 98.4 & 2.39 & 550 & 2.85 & 10.21 & 12.50 & $1.34-100$ \\
\hline Co-HTST-AP ${ }_{2}$ & $3.0-7.0$ & $4.5-5.9$ & 98.5 & 2.42 & 555 & 2.84 & 10.35 & 12.79 & $1.34-97$ \\
\hline Co-HTBT-AP 1 & $2.5-6.4$ & $3.8-5.3$ & 98.8 & 2.52 & 558 & 2.90 & 10.07 & 12.59 & $1.32-100$ \\
\hline Co-HTBT-AP 2 & $2.8-6.7$ & $4.0-5.5$ & 98.9 & 2.55 & 560 & 2.93 & 10.22 & 12.77 & $1.30-100$ \\
\hline Co-HNTP-AP 1 & $2.3-6.1$ & $3.6-4.9$ & 99.3 & 2.75 & 562 & 2.96 & 10.93 & 13.68 & $1.25-100$ \\
\hline $\mathrm{Co}-\mathrm{HNTP}-\mathrm{AP}_{2}$ & $2.5-6.2$ & $3.8-5.0$ & 99.5 & 2.90 & 565 & 3.01 & 10.02 & 12.92 & $1.25-100$ \\
\hline
\end{tabular}



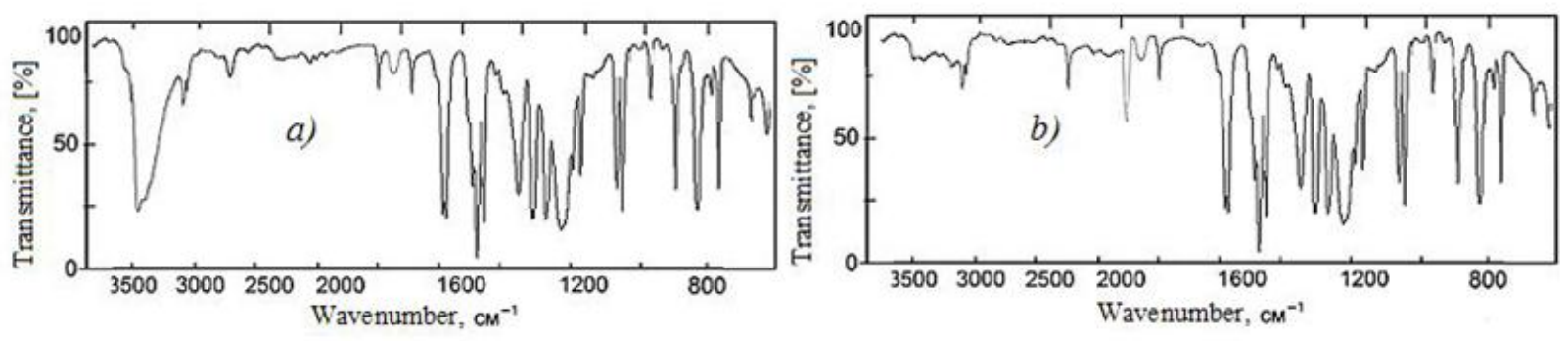

Fig.4. IR spectra of $\operatorname{HATP}(a)$ and the $\mathrm{Co}(\mathrm{II})-\mathrm{HATP}-\mathrm{AP}_{1}(b)$.

The existence of clearly defined absorption bands at $2410-2415 \mathrm{~cm}^{-1}$ in the IR spectrum of the complex indicates the coordination of the Am in the protonated form [15]. The disappearance of the band at $2580 \mathrm{~cm}^{-1}$, characteristic for the spectrum of HATP, and appearance of corresponding bands in the spectrum of the complex, which are shifted toward lower frequency, suggests that the sulphur atoms are involved in complex formation. The observed de-<smiles>CCN[C+]c1ccccc1OCc1cccc(N)c1</smiles>

Influence of interfering ions. The influence of elements, often accompanying cobalt in various objects, as well as the influence of masking substances, is considered. The influence of the It has been found that the determination of cobalt with OP and AP is not adversely affected by alkali and alkaline-earth metals, $\mathrm{W}(\mathrm{VI}), \mathrm{Mo}(\mathrm{VI}), \mathrm{Mn}(\mathrm{II}), \mathrm{Pb}(\mathrm{II}), \mathrm{V}(\mathrm{V}), \mathrm{Cr}(\mathrm{III})$ etc. In the optimal conditions, the complexformation strongly interferes with $\mathrm{Fe}(\mathrm{III})$, $\mathrm{Cu}(\mathrm{II}), \mathrm{Zn}(\mathrm{II}), \mathrm{Ni}(\mathrm{II})$. To eliminate the effect of zinc, cobalt can be determined in phosphate buffer media, with zinc completely masked. To eliminate the influence of iron and nickel, the possibility of acidification after complex formation under optimal conditions has been studied, since cobalt with OP and AP forms kinetically inert complexes. It turned out that acidification up to a $\mathrm{pH}$ of 0.8 does not affect the optical density of the solution. In acidic media, iron and nickel complexes are unstable, and as a result the selectivity of the reaction during acidification significantly recourses. Complexes of copper in acid media are stable, therefore, to crease in the intensity of the absorption bands at $3200-3600 \mathrm{~cm}^{-1}$ with a maximum at $3460 \mathrm{~cm}^{-1}$ and the appearance of a broad band in the region of 3050-3150 $\mathrm{cm}^{-1}$ shows that the hydroxyl group participates in the formation of a coordination bond (Figure 4).

Proceeding from the obtained data, we propose the following structure for the extracted ternary complex:<smiles>CN(C)c1ccccc1O</smiles>

eliminate its influence, the possibilities of using masking agents have been studied. It turned out that the definition of cobalt with $\mathrm{OP}$ and $\mathrm{AP}_{2}$ does not contain up to $250 \mathrm{mg}$ of oxalate, tartrate, citrate and fluoride ions, thiourea, ascorbic acid, $0.8 \mathrm{~g}$ of pyrophosphate, up to $0.2 \mathrm{~g}$ of hydrogen peroxide, up to $0.05 \mathrm{~g}$ of EDTA and hydroxylamine unitol interfere. The presence of thiourea greatly increased the selectivity factor in the presence of copper. The results are shown in Table 2.

Effect of Co(II) Concentration. The adherence to Beer's law was studied by measuring the absorbance value of the series of solutions containing different concentrations of the metal ion. A linear calibration graph drawn between absorbance and the metal ion concentration indicates that $\mathrm{Co}$ (II) may be determined in the range $0.05-4.0 \mu \mu \mathrm{g} / \mathrm{ml}$ (Table 1 ). The pertaining calibration graph is shown in the Figure 5. Table 3 shows the data allowing to compare the analytical characteristics of the methods for determining cobalt with some methods already known [16-27]. 
Analytical applications. The proposed method under the already established optimum conditions was applied for the determination of

Co(II) in various objects. The results presented in Table 4 indicate the successful applicability of the proposed method to real sample analysis.

Table 2. Effect of concomitant ions on the results of the photometric determination of cobalt(II) (40 $\mu \mathrm{g} / 25 \mathrm{ml}$ of cobalt)

\begin{tabular}{|c|c|c|c|c|c|}
\hline \multirow{2}{*}{$\begin{array}{l}\text { Concomitant } \\
\text { ions }\end{array}$} & \multicolumn{5}{|c|}{ Admissible weight excess of concomitant ions by weight } \\
\hline & $\mathrm{HATP}+\mathrm{AP}_{2}$ & $\mathrm{HTP}+\mathrm{AP}_{2}$ & $\mathrm{HTST}+\mathrm{AP}_{2}$ & $\mathrm{HTBT}+\mathrm{AP}_{2}$ & $\mathrm{HNTP}+\mathrm{AP}_{2}$ \\
\hline $\mathrm{Mg}$ & 1900 & 1950 & 1930 & 1800 & 1900 \\
\hline $\mathrm{Cu}(\mathrm{II})$ & 40 & 50 & 50 & 45 & 60 \\
\hline Ti(IV) & 75 & 80 & 85 & 70 & 70 \\
\hline $\mathrm{Ni}(\mathrm{II})$ & 50 & 60 & 50 & 65 & 60 \\
\hline $\mathrm{Mn}(\mathrm{II})$ & 110 & 100 & 110 & 110 & 90 \\
\hline $\mathrm{Zn}(\mathrm{II})$ & 85 & 95 & 80 & 75 & 75 \\
\hline $\mathrm{Cd}(\mathrm{II})$ & 80 & 85 & 80 & 80 & 70 \\
\hline $\mathrm{Pb}(\mathrm{II})$ & 120 & 125 & 130 & 120 & 110 \\
\hline $\mathrm{Al}(\mathrm{III})$ & 150 & 160 & 160 & 155 & 140 \\
\hline $\mathrm{Fe}(\mathrm{III})$ & 80 & 75 & 70 & 85 & 60 \\
\hline $\mathrm{Bi}(\mathrm{III})$ & 160 & 170 & 165 & 160 & 140 \\
\hline $\mathrm{Ga}(\mathrm{III})$ & 150 & 140 & 130 & 135 & 120 \\
\hline$\dot{\mathrm{In}}(\mathrm{III})$ & 120 & 125 & 125 & 110 & 110 \\
\hline $\mathrm{Sc}(\mathrm{III})$ & 120 & 100 & 120 & 125 & 90 \\
\hline $\mathrm{Cr}(\mathrm{III})$ & 130 & 135 & 120 & 90 & 100 \\
\hline $\mathrm{Zr}(\mathrm{IV})$ & 150 & 160 & 160 & 150 & 145 \\
\hline Hf(IV) & 140 & 130 & 145 & 140 & 145 \\
\hline $\mathrm{Nb}(\mathrm{V})$ & 75 & 75 & 75 & 75 & 75 \\
\hline $\mathrm{Ta}(\mathrm{V})$ & 75 & 75 & 75 & 75 & 75 \\
\hline $\mathrm{V}(\mathrm{V})$ & 90 & 80 & 90 & 95 & 100 \\
\hline $\mathrm{Mo}(\mathrm{VI})$ & 100 & 120 & 110 & 100 & 90 \\
\hline $\mathrm{W}(\mathrm{VI})$ & 120 & 120 & 120 & 110 & 100 \\
\hline $\mathrm{F}^{-}$ & 200 & 180 & 190 & 200 & 180 \\
\hline $\mathrm{HPO}_{4}{ }^{2-}$ & 300 & 280 & 290 & 300 & 300 \\
\hline $\mathrm{C}_{2} \mathrm{O}_{4}{ }^{2-}$ & 130 & 140 & 150 & 130 & 120 \\
\hline SCN & 250 & 260 & 260 & 240 & 245 \\
\hline Ascorbic acid & 200 & 210 & 200 & 180 & 190 \\
\hline Tartaric acid & 200 & 180 & 170 & 200 & 190 \\
\hline
\end{tabular}

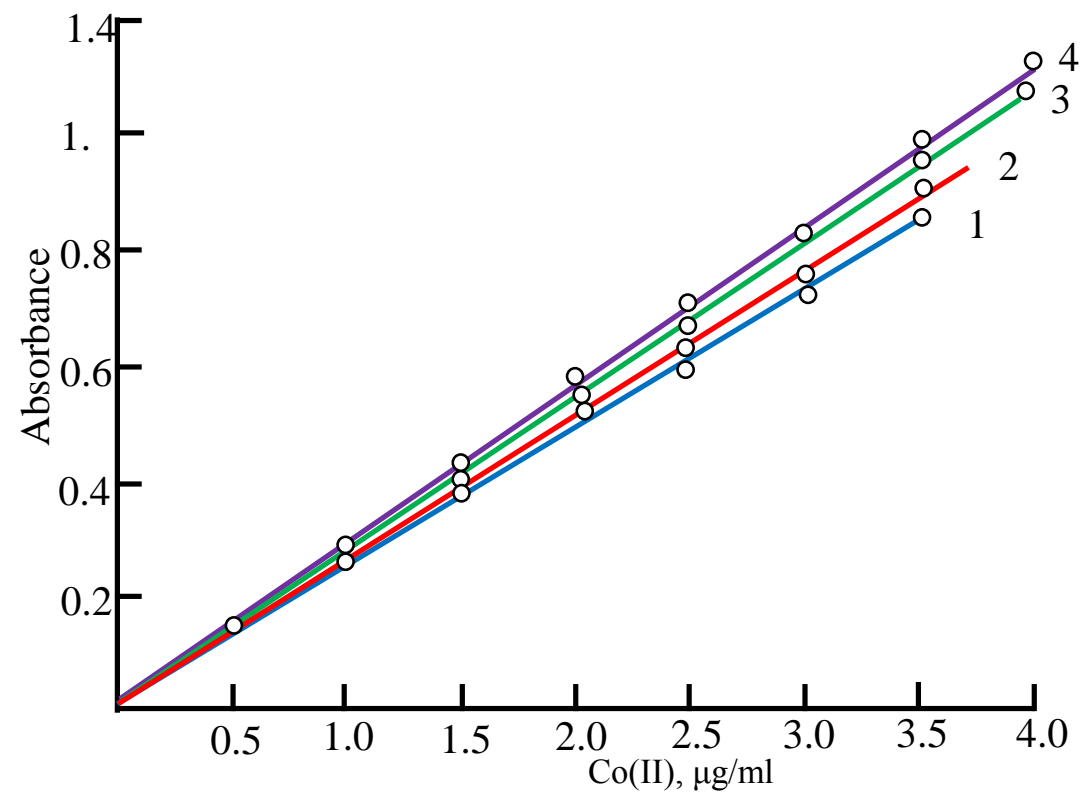

Fig. 5. Analytical determination of $\mathrm{Co}(\mathrm{II}): 1-\mathrm{Co}-\mathrm{HATP}-\mathrm{AP}_{2}, 2-$ $\mathrm{Co}-\mathrm{HTP}-\mathrm{AP}_{2}, 3-\mathrm{Co}-\mathrm{HTST}-$ $\mathrm{AP}_{2}, 4-\mathrm{Co}-\mathrm{HNTP}-\mathrm{AP}_{2} ; C_{\mathrm{OP}}=$ $(1.10-2.25) \cdot 10^{-3} \mathrm{~mol} / \mathrm{L}^{-1}, C_{\mathrm{AP}}=$ $(0.92-1.24) \cdot 10^{-3} \mathrm{~mol} / \mathrm{L}, \lambda=540$ nm, pH 4.0-6.0, SF-26, $l=1.0 \mathrm{~cm}$. 
Table 3. Comparative characteristics of the methods for determining cobalt

\begin{tabular}{|l|c|c|c|c|c|}
\hline \multicolumn{1}{|c|}{ Reagent $(s)$} & $\mathrm{pH}$ & $\lambda, \mathrm{nm}$ & $\varepsilon \cdot 10^{-4}$ & $\begin{array}{c}\text { Beer's law range, } \\
\mu \mathrm{g} \cdot \mathrm{ml}^{-1}\end{array}$ & $\mathrm{R}_{\mathrm{ef}} \cdot$ \\
\hline 1-hydroxy-2-naphthoic acid + aniline & $6.0-8.0$ & 575 & 1.08 & $0.25-110$ & {$[16]$} \\
\hline diantypyrilmethane+naphthalene-2-sulfonic acid & $0.5 \mathrm{M} \mathrm{HCl}$ & 615 & 1.9 & $20-150$ & {$[17]$} \\
\hline$p$-methylisonitroasetophenone & $6.8-7.8$ & 380 & 2.3 & $0.1-4.0$ & {$[18]$} \\
\hline $\begin{array}{l}\text { 4-(2-pyridylazo)resorcinol+xylometazoline } \\
\text { hydrochloride }\end{array}$ & $7.0-8.0$ & 535 & 4.2 & $0-1.6$ & {$[19]$} \\
\hline $\begin{array}{l}\text { 4-(2-pyridylazo)resorcinol+2-(4-iodophenyl)-3- } \\
\text { (4-nitrophenyl)-5-phenyl-2H-tetrazolium chloride }\end{array}$ & 4.7 & 515 & 5.0 & 2.6 & {$[20]$} \\
\hline $\begin{array}{l}\text { 4-(2-thiazolylazo)resorcinol+2,3,5-triphenyl-2H- } \\
\text { tetrazolium chloride }\end{array}$ & $5.2-5.8$ & 525 & 4.26 & $0.2-1.5$ & {$[21]$} \\
\hline Nitrotetrazolium chloride & $2.5-4.5$ & 630 & & & {$[22]$} \\
\hline 4-(2-thiazolylazo)resorcinol + zephyramine & $6.7-10$ & 550 & 3.42 & $2.0-5.0$ & {$[23]$} \\
\hline $\begin{array}{l}\text { 4-(2-pyridylazo)resorcinol+1,4-diphenyl-1-(3- } \\
\text { phenylamino)-1H-1,2,4-triazolol }\end{array}$ & 5.3 & 520 & 6.0 & 1.7 & {$[24]$} \\
\hline 2,4-dihydroxyasetophenone & 9.5 & 390 & 2.7 & $0.12-1.77$ & {$[25]$} \\
\hline Bromopyrogallol red + Tiven 80 & 2.0 & 388 & 0.06 & $0.25-40$ & {$[26]$} \\
\hline 1-allyl-3- (5-chloropyridyl) & 3.5 & 495 & 1.7 & & {$[27]$} \\
\hline OP + AP & & & see Table 1 & \\
\hline
\end{tabular}

Table 4. Results of cobalt determination in industrial and natural materials $(n=6, P=0.95)$

\begin{tabular}{|c|c|c|c|c|c|}
\hline \multirow[b]{3}{*}{ Reagent } & \multicolumn{5}{|c|}{ Found cobalt $\bar{X} \pm t_{P} S / \sqrt{n}, \% ;\left(S_{r}\right)$} \\
\hline & \multicolumn{5}{|c|}{ Analyzed material } \\
\hline & $\begin{array}{l}\text { Steel M } 441 \\
(0.012 \% \mathrm{Co})\end{array}$ & $\begin{array}{c}\text { Steel } \\
\text { НМц2,5/M 627x } \\
(0.055 \% \text { Co })\end{array}$ & Plant* & $\begin{array}{l}\text { Sewage } \\
\text { water }\end{array}$ & $\begin{array}{c}\text { Bottom } \\
\text { sediments }\end{array}$ \\
\hline $\mathrm{HATP}-\mathrm{AP}_{2}$ & $\begin{array}{c}0.014 \pm 0.0071 \\
(0.057)\end{array}$ & & $\begin{array}{l}(2.1 \pm 0.61) \cdot 10^{-4} \\
\quad(0.043)\end{array}$ & $\begin{array}{c}0.45 \pm 0.02 \\
(0.024)\end{array}$ & $\begin{array}{c}1.34 \pm 0.07 \\
(0.012)\end{array}$ \\
\hline $\mathrm{HTP}-\mathrm{AP}_{2}$ & & $\begin{array}{l}0.055 \pm 0.1200 \\
(0.023)\end{array}$ & & $\begin{array}{l}0.485 \pm 0.083 \\
(0.032)\end{array}$ & \\
\hline $\mathrm{HTST}-\mathrm{AP}_{2}$ & $\begin{array}{c}0.015 \pm 0.0011 \\
(0.029)\end{array}$ & & & & $\begin{array}{c}1.30 \pm 0.09 \\
(0.044)\end{array}$ \\
\hline HNTP-AP 2 & $\begin{array}{c}0.012 \pm 0.0015 \\
(0.036)\end{array}$ & $\begin{array}{l}0.053 \pm 0.0019 \\
(0.034)\end{array}$ & & $\begin{array}{c}0.512 \pm 0.01 \\
(0.053)\end{array}$ & \\
\hline ПАР-ТХ* & & & $\begin{array}{l}(9.43 \pm 0.56) \cdot 10^{-4} \\
(0.054)\end{array}$ & & $\begin{array}{c}1.29 \pm 0.05 \\
(0.019)\end{array}$ \\
\hline ДАМ-НСК* & $\begin{array}{l}0.013 \pm 0.0011 \\
(0.043)\end{array}$ & & $\begin{array}{c}(8.95 \pm 0.47) \cdot 10^{-4} \\
(0.035)\end{array}$ & $\begin{array}{l}0.490 \pm 0.050 \\
(0.041)\end{array}$ & \\
\hline OHK-An* & & $\begin{array}{l}0.054 \pm 0.102 \\
(0.016)\end{array}$ & $\begin{array}{c}(9.15 \pm 0.63) \cdot 10^{-4} \\
(0.047)\end{array}$ & & $\begin{array}{c}1.26 \pm 0.05 \\
(0.024)\end{array}$ \\
\hline
\end{tabular}

* Note: The cobalt content in natural objects is in mg/kg; PAR - 4-(2-pyridylazo)resorcinol; TX - 2,3,5-triphenyl-2Htetrazolium chloride; DAM - Diantypyrilmethane; NSA - naphthalene-2-sulfonic acid; HNA - 1-hydroxy-2naphthalene acid; An - aninlin.

\section{Conclusions}

1. Mixed-ligand complexes of cobalt(II) with OP and Am have been studied by spectrophotometry. Extraction of mixed ligand complexes is maximum at $\mathrm{pH} 3.6-6.3$. The optimal conditions for the formation and extraction of mixed-ligand compounds have been found.

2. The molar ratio of the reacting $\mathrm{Co}(\mathrm{II})$, $\mathrm{OP}$ and AP species is 1:2:2. The general formula of the ternary complexes is $\left[\mathrm{Co}(\mathrm{OP})_{2}\right](\mathrm{APH})_{2}$. They can be regarded as ion-associates between doubly charged anionic chelates $\left[\mathrm{Co}(\mathrm{OP})_{2}\right]^{2-}$ and protonated AP species.

3. The developed method retains specific interaction of cobalt(II) with $\mathrm{OP}$ and $\mathrm{AP}$ to form a colored complex and has good sensitivity at room temperature. The proposed method has significant advantage over the other spectrophotometric methods in terms of simplicity 
and sensitivity. This proposed method provides good precision and accuracy. A procedure has been developed for extraction-spectrophotometric determination of cobalt in various objects.

\section{References}

1. Piatneytckii I.V. Analiticheskaia himiia kobalta. M.: Nauka, 1965. $256 \mathrm{~s}$.

2. Umland F., Iansen A., Tirig D., Viunsh G. Kompleksnye soedineniia $\mathrm{v}$ analiticheskoi himii. Teoriia i praktika primeneniia. M.: Mir, 1975. $531 \mathrm{~s}$.

3. Kuliyev K.A., Verdizadeh N.A. Spectroscopic investigation of the complex formation of niobium using 2,6-dithiolphenol and aminophenols. Amer. J. Analytical Chem. 2015. V. 6. No 5. P. 746-756.

4. Kuliev K.A., Verdizadeh N.A., Gadjieva A.B. Liquid-liquid extraction and spectrophotometric determination of molybdenum with 2,6-dithiolphenol and its derivatives in the presence of hydrophobic amines. Chem. J. 2015. V. 5. No 3. P. 45-53.

5. Kuliyev K.A. Verdizadeh N.A., Gadjieva A.B, Mamedova S.A. Spectroscopic investigation complex formation of molybdenum with 2,6-dithiolphenol and its derivatives in the presence of hydrophobic amines. Int. J. Chem. Studies. 2016. V. 4. No 3. P. 42-48.

6. Kuliyev K.A. Spectroscopic investigation complex formation of vanadium using 2,6-dithiol-4-methylphenol and hudrophob amins. J. Adv. Chem. 2015. V. 11. No 4. P. 3487-3497.

7. Kuliyev K.A., Verdizade N.A. Spectroscopic investiqation complex formation of vanadium using 2,6-dithiolphenol and hydrofob amins. Amer. J. of Chem. 2015. V. 5. No 1. P. 10-18.

8. Zalov A.Z., Verdizede N.A., Dzhamalova R.I. Ekstraktcionno-fotometricheskoe opredelenie niobium (V) s 2-gidroksi-5-bromtiofenolom i gidrofobnymi aminam. Azerb. Chem. Journ. 2011. № 1. S. 97-102.

9. Zalov A.Z., Amanullayeva G.I. Spectrophotometric determination of cobalt(II) in a liquid-liquid extraction system containing 2-hydroxy-5-iodothiophenol and diphenylguanidine. J. Appl. Sci. 2016. V. 2 No 7. P. 17-25.

10. Korostelev P.P. Prigotovlenie rastvorov dlia himiko-analiticheskikh rabot. M: Izd-vo AN SSSR, 1961. $218 \mathrm{~s}$.

11. Marchenko Z., Baltcezhak M. Metody spektrofotometrii $\mathrm{v}$ UF $\mathrm{i}$ vidimoi oblastiakh $\mathrm{v}$ neorganicheskom analize. M.: Binom, 2007. $711 \mathrm{~s}$.

12. Kuliev A.M., Aliev Sh.R., Mamedov F.N., Movsumzade M. Sintez aminometilnykh proizvodnykh 2-oksi-5-tret-alkiltiofenolov i ikh rasshcheplenie tiolami Zhurn. org. himii. 1976. T. 12. № 2. C. 426-430.

13. Bulatov M.M., Kalinkin I.P. Prakticheskoe rukovodstvo po fotokolorimetricheskim i spektrofoto- metricheskim metodam analiza. M.: Himiia. 1986. $432 \mathrm{~s}$.

14. Nazarenko V.A., Poluektova E.N. Izuchenie himizma reaktcii ionov mnogovalentnykh elementov $\mathrm{s}$ organicheskimi reagentami. Vzaimodeistvie volframa s 8-merkaptohinolinom. Zhurn. analit. himii. 1971. T. 26. № 7. S.1331-1338.

15. Bellami L. Infrakrasnye spektry slozhnykh molekul. M.- L.: Mir, 1963. 590 s.

16. Salahova F.I. Spektrofotometricheskoe issledovanie kompleksoobrazovaniia kobalta s 1-oksi-2naftoinoi kislotoi i anilinom. Azerb. Chem. Journ. 2011. № 1. S. $184-190$.

17. Denisova S.A., Lesnov A.E., Petrov B.I. Ekstraktciia tiocyanatnykh kompleksov metallov $\mathrm{v}$ rasslaivaiushcheisia sisteme voda-diantipirilmetannaftalin-2-sulfokislota. Izv. Altaiskogo gos. un-ta. Ser. "Himiia". 2013. T. 1. №1. S. 151-155.

18. Baytak S., Turker A.R. Determination of lead and nickel in environmental samples by flame atomic absorption spectrometry column solid-phase extraction on Ambersorb-572 with EDTA. J. Hazard. Mater. 2006. V. 129. P. 130-136.

19. Bhadani S.N., Tewari M., Agrawal A., Sekhar C. Extractive-photometric determination of cobalt(II) in steels using 4-(2-pyridylazo)resorcinol and xylometazoline hydrochloride. J. Indian Chem. Soc. 1998. V. 75. No 3. P. 176-177.

20. Divarova V.V., Gavazov K.B., Lekova V.D., Dimitrov A.N. Spectrophotometric investigations on liquid-liquid extraction systems containing cobalt, 4-(2-pyridylazo) resorcinol and tetrazolium salts. Chemija. 2013. V. 24. No 2. P. 81-87.

21. Divarova V., Racheva P., Lekova V. Spectrophotometric determination of cobalt(II) in a liquidliquid extraction system containing 4-(2-thiazolylazo) resorcinol and 2,3,5-triphenyl-2H-tetrazolium chloride. J. Chem. Technol. and Metallurgy. 2013. V. 48. No 6. P. 623-630.

22. Dospatliev L., Georgieva N.V., Pavlov A.I., Yaneva Z. Extraction-spectrophotometric determination of cobalt in soils by the application of iodine nitrotetrazole chloride. Trakia J. Sci. 2010. V. 8. No 2. P. 235-241.

23. Kazumasa U. The Extraction and spectrophotometric determination of cobalt (II) with 4-(2-thiazolylazo)-resorcinol and zefiramin. Bull. Chem. Soc. Jpn. 1979. V. 52. No 4. P. 1215-1216.

24. Barhate V. D., Patil M. R. Extraktion and spectrophotometric determination of cobalt (II) with pmethylisonitrosoasetophenone. Curr. Sci. 1989. V. 58. No 6. P. 291-293.

25. Raceva P.V., Gavazov K.B., Lekova V.D., Dimitrov A.N. Complex formation in a liquid-liquid extraction system containing cobalt(II), 4-(2-pyridylazo)resorcinol, and nitron. J. Mater. 2013. V. 30. No 1. P. 1-7. 
26. Shar G.A., Soomro G.A. Spectrophotometric determination of cobalt(II) as complexes with bromopyrogallol red in micellar media of twen 80. J. Chem. Soc. Pak. 2006. V. 28. No 5. P. 444-447.
27. Agarwal S., Mathur S.P. Photometric determination of cobalt(II) by absorption of its 1-allyl3-(5-chloropyridyl)thiourea complex on polyurethane foam. Indian J. Chem. 2001. V. 40. P. 544-545.

\section{KOBALTIN(II) HIDROFOB AMIN ISSTIRAKINDA 2-HIDROKSITTIOFENOL VӘ ONUN TÖRӘMӘLӘRI İLӘ KOMPLEKS ӘMӘLӘGӘLMӘSI VӘ EKSTRAKSIYYASI}

\section{ə.Z.Zalov, N.A.Verdizadə, Ş.ə.İbrahimova, G.V.Babayeva}

Spektrofotometrik metodla kobaltın hidrofob amin iştirakinda oksitiofenol (OF) \{2-hidroksitiofenol (HTF) və onun törəmələri (2-hidroksi-5-amintiofenol (HATF), 4-hidroksi-3-tiosulfoturşu (HTST), 4-hidroksi-3-tiolbenzoy turşusu (HTBT), 4-nitro-2-hidroksitiofenola (NHTF)\} ilə müxtəlifliqandlı kompleks (MLK) əmələ gətirməsi və ekstraksiyası tədqiq edilmişdir. MLK əmələ gəlməsi pH 3.6-6.3 intervalında baş verir. Komplekslərin əmələgəlmə və ekstraksiya şəraiti, tərkibi, fiziki-kimyəvi və analitik xassələri müəyyən edilmişdir. MLK ekstraktı kobaltın $0.05-3.2 \mathrm{mkq} / \mathrm{ml}$ qatılıq intervalında Ber qanununa tabe olur. Yeni işlənilmiş metodika müxtəlif obyektlərdə kobaltın ekstraksiyalı-spektrofotometrik təyininə tətbiq edilmişdir.

Açar sözlor: kobalt, ekstraksiya, spektrofotometriya, ion-assosiat, hidrofob aminlar, hidroksitiofenol.

\section{КОМПЛЕКСООБРАЗОВАНИЕ И ЭКСТРАКЦИИ КОБАЛЬТА (II) С 2-ГИДРОКСИТИОФЕНОЛОМ И ЕГО ПРОИЗВОДНЫХ В ПРИСУТСТВИИ ГИДРОФОБНЫХ АМИНОВ}

\section{А.З.Залов, Н.А.Вердизаде, Ш.А.Ибрагимова, Г.В.Бабаева}

Спектрофотометрическими методами изучены реакции образования разнолигандные комплексы кобальта (II) c окситиофенолом (ОР) \{2-гидрокситиофенолом (НTP) и его производными (2-гидрокси-5-аминтиофенол (НАТР), 4-гидрокси-3-тиолсульфоновая кислота (HTSA), 4-гидрокси-3-тиолбензойной кислоты (HTBA), 4-нитро-2гидрокситиофенола (HNTP)\} в присутствии гидрофобных аминов (Am). Оптимальный интервал кислотности, при котором оптическая плотность максимальна и постоянна, находится прирН 3.6-6.3. Определены условия образования и экстракции, состав, физико-химические и аналитические свойства комплексов. Экстракты ионных ассоциатов кобальта подчиняются основному закону светопоглощения при концентрациях $0.05-3.2$ мкг/ мл. Разработана методика экстракционно-спектрофотометрического определения кобальта в разных объектах.

Ключевые слова: кобальт, экстракция, спектрофотометрия, ион-ассочиат, гидрофобные амины, гидрокситиофенол. 